\title{
A Research on Postgraduate English Curriculum Based on the Academic English*
}

\author{
Yuan Kong \\ School of Foreign Languages, Jining Medical University, Jining, China
}

\begin{abstract}
In this paper, the current research situation of academic English is reviewed. From the perspective of curriculum research, we investigate the implementation of Public English curriculum and the needs of academic English, and then put forward some specific measures for the construction of academic English courses. This paper mainly discusses three aspects of the requirement, setting and teaching of academic English courses. On the basis of previous studies, there are not many academic English courses for postgraduate students in Colleges and universities. According to the theory that education is ahead of the economic development, it is an advanced research path to explore the establishment of academic English course in the teaching of postgraduate English. The object of this study is a very representative University in a certain area, which can reflect the overall level of higher education in the region to a certain extent. Both the hardware and the software facilities can provide practical possibilities for the proposal and implementation of this article, and also have a reference for the national colleges and universities.
\end{abstract}

Index Terms—Academic English, postgraduates, curriculum reform

\section{INTRODUCTION}

Under the background of internationalization of science, technology and education in China, postgraduates are frequently required to attend academic lectures, participate in academic seminars, and conduct academic exchanges. The graduate English Teaching in China has always been dominated by general English, which is unable to meet the requirements of the current era for Postgraduates' Academic English ability. It has attracted the attention of scholars in educational circles for academic English (EAP). Since twenty-first Century, the teaching of College English has been reformed many times, and the reform of postgraduate English has gradually entered the public view (Cai, 2014). In 2004, the Ministry of Education issued the Master's Degree and Doctoral Degree English Teaching Syllabus. It clearly pointed out that postgraduate English teaching is aimed at students' learning and international communication in English. The Outline of the National Medium and Long-Term Educational Reform and Development Plan (2010-2020), issued in 2010, puts forward that we should improve the level of education internationalization and cultivate a large number of international talents with international vision, international rules and participation in international affairs and international competition. This requires graduate students to be able to use English to communicate in various disciplines and fields. At present, graduate students generally improve the standard of English, basic English course has been unable to meet the individual English learning and social needs of graduate students, Graduate English curriculum reform is imperative, in the graduate student stage set up academic English course has become the only way which must be passed postgraduate English curriculum reform and development.

\section{AN ANALYSIS Of THE NECESSITY OF ACADEMIC ENGLISH COURSES}

\section{A. The Need for the Development of the Subject}

In the field of foreign language education in Colleges and universities, foreign language education has been gradually combined with subject and professional teaching. Foreign language teaching is no longer just a purely language learning, but more for discipline and professional services (Cai, 2015). This phenomenon can be reflected in the ESP courses offered by universities, such as business English, medical English, tourism English and law English. Most of these courses are in the form of professional compulsory courses, and elective courses for other non-English majors are not popularized. At present, the demand for academic English courses is more common in Colleges and universities in China than in professional English courses. In the developed areas of the world, academic English is one of the required courses for international students. Though the degree of internationalization of Chinese universities is not balanced, the school leaders attach great importance to the international exchanges and cooperation of discipline development. Some

\footnotetext{
* Funding Sources: A Project of Shandong Province Higher Educational Humanities and Social Sciences Research (Grant No. J17RA054); An Industry-University Cooperative Project of Ministry of Education; Social Science Planning Research Program of Shandong Province (Grant No. 17CWZJ38); Research Program of Young Teachers' Education and Teaching of Shandong Province (Grant No. 16SDJ232); Key Program in Art Science of Shandong Province (Grant No. ZX2015005); Youth and Adolescents Quality Education Work Planning Program of Shandong Province (Grant No. 13AJY090); Scientific Research Program of Jining Medical University (Grant No. JY2013RW032); The Visiting Scholar Funded Program of Young Backbone Teachers in Jining Medical University; College Students' Innovative Training Project of Jining Medical University (Grant No. cx2017052); Scientific Research Project of College Students in Jining Medical University (Grant No. JYXS2017RW017)
} 
universities cooperate with foreign universities to establish new departments and new specialties. It helps to cultivate students' academic thinking and improve their ability to participate in academic activities in English and the ability of relying on discipline development, but also help universities and students understand the international discipline development newest achievement of domestic professional development and promotion of state discipline and promote international exchanges and cooperation.

\section{B. The Needs of Students}

The English Syllabus for Non-English Major Postgraduates in our country stipulates that graduate students should be able to use this tool of English to carry out their professional learning, research and international communication (Du, 2015). As a graduate student of various disciplines, high-end graduates often use a lot of foreign literature to acquire and master the latest information of this specialty, and communicate with professionals in oral or written English. However, not every student of English has its unique linguistic features in vocabulary, syntax, rhetoric and discourse, the traditional general courses in English language knowledge cannot cover all disciplines of core components, and graduate students in professional cannot communicate with English. Therefore, special and systematic academic English learning is very necessary.

\section{The Needs of Society}

To train talented people with international competitiveness is the core goal of the training of higher education talents in China. Compared with the past, our era has undergone tremendous changes. In the age of information and technology, the competitiveness of talents is the most important soft power of national development. In the political, economic, cultural and other aspects of our country's communication and cooperation in the world, the demand for diversified comprehensive talents is becoming higher and higher (Liu, 2004). As a high-level talent trained by the state, postgraduate is not only required to have solid knowledge and skills, but also to have a high level of foreign language that can participate in international affairs. For literacy of college talents and social development mainly reflects the creation of courses in Colleges and universities, according to the requirements of the quality standard of national development strategy and personnel training, improve the graduate English level and improve their ability to use English to do research work, to improve their English application ability has become an important task of English Teaching for Postgraduates in china (Jia, 2014). In the University, in addition to the cultivation of foreign language talents, non-English Majors' academic and professional education is not enough, many graduate students can not use English to retrieve the latest research results, read foreign literature, foreign participation in international academic conferences, the ability training and lack of social participation in international affairs, need a large number of talents the demand is in conflict. In order to meet the needs of talents training in the society, the postgraduate English Curriculum in Chinese universities need to make corresponding adjustments, so as to transform the general English ability of graduate students to cultivate their academic English and further to the direction of professional English (Rao, 2005).

\section{The Problems of General English Oriented Public Course}

\section{A. Different Colleges and Universities Have Great Differences in Curriculum Arrangement}

With the increase of autonomy of postgraduate training institutions, colleges and universities have made many reforms on Public English teaching. Even some colleges and universities have more credits and hours of Public English courses than professional classes.

\section{B. It Lacks of Cohesion with College English Courses}

Some college students study English curriculum orientation is not clear, the continuation of undergraduate curriculum content of English courses, pay no attention to the differences between graduate students and undergraduates in learning needs and learning characteristics, such as graduate students have more academic exchanges and professional learning needs, which requires the reform of English curriculum, meet graduate students under the new situation of English learning needs. Taking writing course as an example, we repeated learning how to write theory from high school, undergraduate to postgraduate, but failed to complete a standardized English academic article. Graduate English course to undergraduate English courses and good convergence, lay a good foundation English writing undergraduate to graduate should combine professional disciplines, increase the subject or interdisciplinary and different subjects, on the basis of practical discourse learning to imitate, rewriting, creation, and accumulation the rich corpus, grasp the corresponding writing skills and writing norms, really improve their academic writing skills, improve Postgraduates' academic research ability.

\section{The Construction of Teachers' Team Must Be Strengthened}

The construction of teaching staff of postgraduate public English curriculum is mainly reflected in the following three aspects: first, the number of teachers is not enough; in recent years, the number of graduate enrollment and the number of graduate students has increased annually, but the number of College English teachers has not increased correspondingly. In Colleges and universities, the number of English classes for postgraduate English is more than fifty 
or sixty. Second, teachers are mainly composed of undergraduate foreign language teachers; undergraduate public English teachers or professional English teachers themselves are not only light on teaching tasks, but now they also need to increase their teaching tasks, teachers' heavy workload and lack of teachers. Third, the graduate students of Public English course lack teacher training. In the era of progress, science and technology in the rapid development of information technology, personnel training in this situation but also to keep up with the pace of social development, especially when the teaching duty teachers should constantly update their knowledge system, teaching contents, teaching methods, teaching ideas to inject new vitality, also the shortage of teachers, teaching the heavy task, in this case it is easy to produce occupation burnout teaching bottleneck, more needs of the local administrative department of education or university teacher training organization.

\section{It Is Unable to Meet the Practical English Needs of Postgraduate Students}

Postgraduate English curriculum mostly follows the undergraduate curriculum mode of foreign language curriculum, attaches importance to the cultivation of students' general comprehensive ability, and does not pay enough attention to students' academic oral communication, academic written communication and the cultivation of professional learning ability in English. In the cultivation of comprehensive ability, we should pay attention to reading ability and despise the improvement of listening and writing ability. According to the survey, colleges and universities usually set up professional English in the second semester of postgraduate, 2 credits, 16 hours, usually by the professional teachers, but due to professional differences, some majors do not set up. From the courses, postgraduate English courses continued and repeated undergraduate English learning content can not meet the basic requirements of international personnel training to master the international language of English and can make a variety of disciplines and professional communication in English.

\section{E. Graduate Students' English Level Is Uneven}

The survey results show that the current level of English proficiency of graduate students is TEM 8 and 4, CET 6 and 4, and CET 4 below. English level can be divided into advanced, intermediate, primary and lower levels. Because of the uneven English level of graduate students, the students who have different English levels are arranged in the same class for teaching. The students of the junior and below level can not be carefully coaching and training, while the middle and senior students can not further improve their English ability and repeat their time and energy. Therefore, the diversification of students' English proficiency will definitely require diversified English courses.

\section{F. The Course Is Single and Lacks of Innovation in the Class}

Graduate English curriculum is similar to undergraduate college English in terms of lesson type, with a single set of class settings, and extensive English Intensive Reading and English listening course. English courses are mostly Basic English courses, and academic and professional English courses are missing. In addition, teachers use the traditional teaching method of teachers' center, teaching is mainly knowledge, teaching means and methods are single, and reading and translation teaching are the main ways (Peng \& Zhang, 2010). This teaching model is difficult to achieve the goal of the graduate students' Public English course. Many colleges and universities in the aspects of teaching hardware and teacher construction cannot meet the needs of teaching. The update speed is far behind the growth rate of graduate enrollment. Graduate English class teaching, teacher's teaching for students of different majors and class teaching are neat and uniform, but they are unable to meet the needs of small class and individualized English teaching

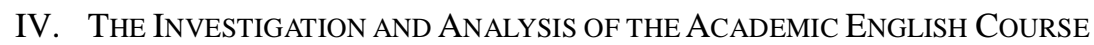

\section{A. The Training of Postgraduates' Academic English Ability in Universities}

In this paper, teachers, teaching materials, teaching activities and academic ability training are used to reflect the importance of the cultivation of students' Academic English ability. Through the analysis of the above four aspects, we can see that the College English curriculum and professional related English textbooks rarely, learn English and learn professional knowledge from; professional teachers is mainly Chinese teaching, not related to the professional English learning; teachers do not pay attention to English literature reading, ignoring students' academic skills in English exercise; school related English academic activities is not much, not actively create English academic atmosphere; both in class teaching and after-school academic guidance, academic and cultural environment, colleges and universities have larger deletions in the cultivation of academic English ability of students.

\section{B. Graduate Students' Academic English Level}

In academic English, the listening and oral level of the students is low. They are unable to complete the task of teaching. The average size of students' Academic English listening and oral expression is inversely proportional to the level of their English proficiency, that is, the higher the English level is, the lower their academic English listening and speaking ability is.

In the field of academic English writing, $40 \%$ of the students think the biggest problem is that the reserve of professional vocabulary is not enough. $30 \%$ of the students have large problems in vocabulary, grammar, structure and genre, and need a large number of revisions. $20 \%$ of the students may have some professional vocabulary, but also have 
some understanding of the formal style, but there are obstacles in the structure and style of the article. $7 \%$ of the students think the biggest problem of their writing is to master the grammatical style of formal style. Only $3 \%$ of the students believe that their vocabulary, grammar, structure and genre can basically meet the requirements of academic publication. English academic publication requirements strictly, in addition to master a large number of professional vocabularies, grammar, style and structure, theme, genre or format, punctuation has special requirements for this usually did not receive English writing training students is undoubtedly a great difficulty.

\section{Suggestions on the Course Setting of Academic English for Non-English Major Graduate Students}

The experts of foreign language education published and expounded their views on "academic English" and "general English". Jigging Cain advocates the transfer of English teaching emphasis from the current general English to the professional English, especially the academic English. Shoran Wang thinks that academic English must be built on the basis of needs analysis, and pay enough attention to academic English. But it does not praise students' English content as the whole content of College English teaching. It is suggested that colleges and universities decide the proportion of academic English based on the actual situation. Qi fang Wen agreed to push forward the English teaching system coexisting with general English and special English, and improve teaching effect by reforming teaching objectives, teaching contents, teaching methods, assessment methods and teaching modes. As different colleges and universities have great differences in school level, location, category and source, the development of academic English Teaching in Colleges and universities in China is not balanced. In addition, the degree of internationalization of higher education in universities is different. There are obvious differences between international scholars and teachers and students, in terms of technology and culture cooperation, overseas students, foreign professors and visiting scholars, and frontier research. The students' needs for academic English (such as overseas visits, listening to English lectures, and learning some English major courses) are different.

\section{A. The Integration of English Learning and Academic Activities}

The construction of academic English course is student centered, method oriented, and four, four and five. Four education refers to higher education, foreign language education, humanistic education, general education academic thinking of mutual penetration; refers to the four ideas, tools and cultural and educational combination; five refers to training with language, communication, academic and cultural exchanges, international competition ability of talent. The academic English course combines language learning with academic activities to enable students to master English skills in the course of academic activities. The goal is the process, namely, the process is the result. In the academic activity level, we have targeted, planned and organized English listening, speaking, reading and writing activities, learning content and academic related methods and academic skills training, making the English curriculum itself an academic demonstration activity (Tang, 2015).

\section{B. The Co-exist of Exemptions and Elective}

Due to the expansion of the enrollment of graduate students, the English level of the graduate students is not balanced. Some students at the undergraduate level English ability is relatively outstanding, had already reached the demands of English postgraduate standard, but there are a lot of basic skills of the students in English listening, speaking, reading, writing and translation being relatively weak. According to this situation, this paper proposed the implementation of the exemption system of graduate English course in Colleges and universities. The study on the English test reaching a certain standard of living can be exempted from general English courses directly into the academic English courses of study. Through the diversion measures, it can avoid the waste of curriculum resources and also help students personalized learning and autonomous learning, which makes the research of English Teaching in English teaching and undergraduate students more fluent.

\section{General English and Academic English}

According to the survey of the English level of postgraduate students in the University, the level of postgraduate English is uneven. In addition, most of the academic English needs of graduate students stay in English reading professional literature, listening to English academic reports, and making English academic speeches and reports. Their academic activities are low in internationalization, which is also closely related to the regional economy and the degree of internationalization of higher education. Considering the level of higher education in Jiangxi Province, the degree of internationalization of higher education and the situation of academic English curriculum at home and abroad, this paper suggests that we should set up an English course in general English and academic English in Colleges and universities.

1. General English curriculum arrangement

The general English curriculum arrangement of postgraduate English Curriculum in universities should first consider the general English course. Only when students have certain Basic English skills can they learn better academic English related to majors and disciplines. In the specific operation, according to the national unified college entrance examination students study English or study the school to organize themselves to develop students' English exam admission grade general English exemption criteria of students who fail to obtain exemption qualifications, must use the 
new English curriculum, the curriculum is a required course, curriculum types into English listening and speaking and reading, writing and translation, aims to cultivate students' basic skills of listening speaking reading writing and translation.

2. The course arrangement of academic English

Academic English is divided into general and special academic English Academic English, opened in a progressive way, obtained a general English exemption qualification for students, can directly go to the general academic English courses, general academic English courses students into academic English course learning (Wang, 2008).

According to the survey, there is a great demand for students' Academic English reading and writing. It is suggested that academic English writing and academic English communication should be offered in the general academic English stage. It mainly teaches students to retrieve and consult literature, select topics, standardize academic writing language, participate in conference exchanges and discussions, and cooperate with groups.

The general academic English course is set up in the second semester, and special academic English is set up in the third semester. Because students have certain professional knowledge, learning academic English is more targeted. General academic English courses for a semester, based on the division of the university students as teaching classes, in particular: literature and history, science and engineering academic English Academic English Academic English and art. Academic English set up time for a semester, mainly teaching on specific subjects, vocabulary, syntax and discourse genre and communicative strategies, thought that the professional needs of service concept for the guidelines, according to disciplines set up different professional English curriculum aims to help students acquire vocabulary, skilled professional language, access to cutting-edge information related to the field, cultivating the ability of students in the professional work in the English context.

\section{The Cooperation between Language Teachers and Professional Teachers}

BALEAP, a professional institution, has a faculty member who is directly engaged in academic English teaching activities. Regular academic exchange meetings are held annually, and English academic courses are evaluated. It has made outstanding contributions to improving the quality of academic English Teaching in the UK, promoting the improvement of teachers' abilities and career development, and promoting the dissemination of research results related to academic English. There is no way to form such a complete system in our current academic English. However, universities in China can learn from the practice of BALEAP in the UK, organize regular academic exchange meetings, regular training for academic English teachers, or select teachers to learn and communicate at colleges and universities that are developing well in academic English. Secondly, cooperation letters between professional teachers and English teachers need to be strengthened. Graduate schools should play the role of leadership, organization and coordination, actively communicate with different colleges and support teachers, and form different teaching groups according to their majors, research directions and interest in teaching. The cooperative teaching of language teachers and professional teachers is various. Considering the integrity and pertinence, it can not only carry out cooperation in every aspect of teaching process, but also divide and cooperate in a specific link of teaching. For example, in the teaching process of writing, professional teachers can guide students' topic selection, research methods, document retrieval and reading, etc. language teachers can check whether students' academic language is standardized.

\section{E. Teaching Materials and Corpus Construction}

First of all, teaching materials can reflect the quality of teaching, is an essential part of the curriculum. The teaching material should be able to reflect the real teaching situation and teaching task, relying on the content of the subject. Therefore, in order to ensure the authenticity and original ecology of textbooks and enable students to adapt to the real and complicated academic English context, we must keep the authenticity of the original language and content. In addition, in order to improve students' academic innovative thinking, try to present different or opposite theme articles, providing students with opportunities to think, contrast, evaluate and communicate (Xia, 2005).

Secondly, we should make full use of the network teaching resources and create a corpus. The convenient network platform and rich learning resources provide the content and method support for the construction of the corpus. Teachers can cultivate students' ability of independent learning and self education, and recommend some good academic corpus and database to help students select high-quality curriculum resources. Corpus is a powerful electronic resource, which stores corpus information in the form of documents (Xia, 2002). It uses the function of computer analysis to present high-frequency language phenomena and characteristics in corpus. For the learning of academic English, we can retrieve context in text by searching key words and index in corpus, and learn how to use it in real context. Teachers can also build their own corpus according to the needs of the curriculum.

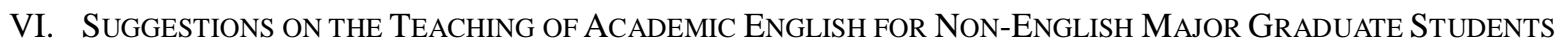

Academic writing is one of the essential English application abilities for Postgraduates in international academic exchanges. Cultivating non-English Major Postgraduates' English academic writing ability has become an essential part of developing their international exchange capacity. Especially in academic exchanges, scholars have less verbal communication opportunities, and most of the academic interaction is carried out in written form. Academic writing ability has a decisive influence on the effect of the dissemination of academic achievements. According to the survey, 
there is a great demand for academic English reading and writing in college students. Taking the academic English writing course as an example, based on summarizing the opinions of Postgraduates' Academic English writing, this paper puts forward some teaching suggestions on Academic English writing.

\section{A. The Combination of Writing Skills Training and Academic Activities and Subject Content}

After years of English learning, graduate students have mastered a certain number of vocabularies, grammar and basic writing skills. Therefore, this stage of writing instruction should seek more advanced learning objectives, cater to the academic writing needs of postgraduates, emphasize professional direction and expand their academic fields. For graduate students, how to improve their academic writing ability, express their academic views and put forward scientific research findings is a common problem when writing (Wen, 2004). Writing skills training and postgraduate academic activities and academic content combination is a major characteristic of postgraduate English writing, in the teaching process of English academic writing courses, teachers should combine professional knowledge and literature, to guide students to read and analyze the structure of the genre, notes cite, specification format and then master the writing form and operation specification. At the same time, we should focus on the understanding and application of strategies in the various steps of academic writing, such as selection, information, first draft, and revision (Wen, 2014).

\section{B. The Combination of Classroom Teaching with Independent and Cooperative Learning after Class}

The graduate students generally have better self-learning ability and self-supervision ability. The awakening of self-awareness of this kind of learning is beneficial to language learning. In teaching organization, it is suggested to combine classroom teaching with after-school independent cooperative learning to give full play to postgraduates' self-learning ability and cooperation consciousness. Teachers need to play a supplementary role in giving effective guidance and timely feedback and evaluation to students.

The teacher in the classroom teaching and practical system of basic theoretical knowledge of English academic writing; reasonable arrangement of teaching content, combined with lecture notes, essays, academic conference reports and other auxiliary materials for teaching; cooperative activities, the students according to different professional or common learning task groups, targeted to carry out teaching activities. After class, independent and cooperative learning includes students' independent self-study, and the after-school counseling service provided by the school. Internet is the best platform and channel for students to learn independently. Rich Internet resources can expand students' corpus input, and students can compare exchange and reflect each other through Internet, and constantly improve their writing level. The establishment of the school after-school tutoring center for academic writing needs students to provide guidance and assistance, academic writing center teachers regularly to guide students, this approach targeted to solve individual students encountered in academic writing difficulties, you can make up for lack of unified class teaching.

\section{Selecting Appropriate Textbooks According to the Classification of Students' Subject and the Level of English}

Through the analysis of the academic English writing materials of domestic graduate students, the author classifies them and puts forward some suggestions for the selection of new textbooks.

1. The current classification of academic English writing materials for graduate students in China

The first is a book written by domestic scholars for all English Academic English writing. Mainly in English academic writing knowledge and skills of case teaching and training, cultivating students' English academic awareness from the aspects of academic discourse structure, words rule, coherence and cohesion, and the application of academic research in writing and communication related to the cultivation of students' practical writing skills. The advantage of this kind of book is to combine reading and writing, and to cultivate students' academic thinking ability of research and discovery based on the empirical and logical characteristics of English academic discourse.

The second kind, the Chinese instruction compiled by the domestic scholars, is the main English Academic Writing Book supplemented by English. This book covers the content more comprehensive, including academic writing basic components (such as methods, results and conclusions) and writing (such as data search, collection and collation, syllabus construction, notes), academic discourse (such as diction, sentence, discourse, etc.). This book will not put in academic English academic writing in the context of training, discourse pattern is easily affected by the influence of mother tongue thinking, the students are prone to writing syntactic monotonous, excessive use of certain words, showing strong stylistic features of spoken English, is not conducive to the cultivation of English academic writing thinking. This kind of book is suitable for English level (Yang, 2009). It is impossible to learn English textbooks directly (Song, 2015). It needs a large number of students with Chinese guidance.

The third is a book on English academic writing by foreign scholars. Domestic experts select foreign high-quality writing materials and introduce a number of more classic textbooks. This kind of book system introduces the basic requirements, format norms and methods and skills of academic writing, covering a wide range of topics, including selecting topics, consulting and collating materials, determining articles outline, and citing references. This kind of book is suitable for students with better English level, which helps to cultivate students' thinking in English writing (Wu, 2014).

2. The selection of Graduate academic English writing materials

From the subjects of colleges and universities use the textbooks directory and content can be seen, the course is a continuation of the University and senior high school English writing skills Professor, although the content according to 
the features of English learning and learning needs of students, set up academic writing, but not from the academic level to improve study on the writing ability of the students (Xu \& Jiang, 2014). Therefore, in the academic English stage after general English, I suggest that graduate students choose their own classes according to their own situations, and there are differences between the textbooks of different subjects, different classes and classes. Academic English writing textbooks are divided into two categories: one is the social science, science, art and academic English reading teaching materials, a total of three copies, according to the different disciplines to students with a book; the other is the special academic English writing teaching, the teaching material has two kinds, one is for primary and intermediate the learner, the other is for senior learners.

Students can choose primary and middle-class or middle-class courses independently according to their English level or needs. In the social sciences at the beginning of the intermediate students as an example, to grant them a social science academic English reading course, reading the one hand to expand student's corpus, accumulated enough input for academic English writing; on the other hand is convenient for teachers with reading course content in academic articles as an example for the teaching of academic English writing teaching is placed in the real context, the actual use of more students (Yin \& Wang, 2015). The other is the intermediate and intermediate academic English writing course (Yang \& Yang, 2013). The selection of this kind of teaching material can be referred to the second category of the academic English writing teaching material, which is compiled by Chinese scholars. Try to choose the teaching material that is capable of improving the ability of academic English writing on the basis of the student level. No kind of teaching material is fully in accordance with the requirements of teaching. No matter what kind of teaching materials to choose, teachers should not be able to copy the content of the teaching material completely according to the status and demand of the students' writing level. Teachers should carry out reasonable selection and arrangement of teaching contents and teaching order, together with the self-made lectures, corpus resources and other electronic resources, classroom teaching and after-school tutoring, combination group and other forms of teaching, so as to give full play to each kind of material use value.

\section{CONCLUSION}

The main purpose of postgraduate English teaching is to cultivate students' ability to read professional books and periodicals more skillfully. Therefore, emphasis must be placed on the application of teaching, combined with the characteristics of professional English, highlighting the training of reading, writing and translation, and correctly dealing with the relationship between reading, writing, translating, listening and speaking. Graduate English teaching should be promoted from reality, pragmatic, and learn widely from others strong points, in strengthening the theoretical research and Practice on the basis of summing up, and strive to explore and establish research suitable for China's English teaching system.

Basic English and professional English are two parts closely related to the whole process of postgraduate English teaching. They undertake the task of training students' ability to get the syllabus. In Basic English, we should try to combine the characteristics of professional English and cultivate the students' ability to use English. Specialized English should consolidate and improve students' ability to acquire in Basic English stage, expand their professional vocabulary, ensure a large number of English reading practices, enable students to truly acquire and communicate information needed by their majors by means of English. The professional teacher is responsible for the material selection and guidance of the foreign language and the writing of abstract or summary; the English teacher is responsible for the writing and reading skills.

\section{REFERENCES}

[1] Cai, J. G. (2014). "From General English to Academic English back to College English Teaching Standard." Foreign Languages and their Teaching (1): 9-14.

[2] Cai, J. G. (2015). "Exploration and Research on General Academic English Evaluation System.” Shandong Foreign Languages Teaching Journal (4): 40-47.

[3] Du, X. S. (2015). "Lexical Chunks in Colloquial Discourse of Different Disciplines based on BASE Corpus." Overseas English (8): 207-208.

[4] Department of higher education of the Ministry of Education. (2004). Requirements for the Teaching of College English Courses (Trial). Beijing: Foreign Language Teaching and Research Press.

[5] Liu, R. Q. (2004). English Language Studies. Beijing: Foreign Language Teaching and Research Press.

[6] Jia, G. M. (2014). "An Enlightenment of the EAP Mode of University of Canberra in Australia on the Reform of English Teaching for Postgraduates in China." Journal of Chongqing University of Technology (6): 118-121.

[7] Peng, S. Y. \& Y. Y. Zhang. (2010). International Academic Exchange and Paper Writing. Beijing: Foreign Language Teaching and Research Press.

[8] Rao, Z. H. (2005). A Course of Postgraduate English Writing and Translation. Jiangxi: Jiangxi University Press.

[9] Song, H. Y. (2015). "The Construction of EAP Oriented College English Curriculum System." Journal of Hubei University of Economics (2): 210-211.

[10] Tang, L. (2015). "On the Selection of Subject Matter of EAP Teaching Materials in Colleges and Universities." Journal of Lanzhou Institute of Education (8): 123-124.

[11] Wang, S. R. (2008). A Report on the Development of Foreign Language Education in Universities and Colleges. Shanghai: 
Shanghai Foreign Languages Education Press.

[12] Wen, Q. F. (2004). A Research Method and Paper Writing in Applied Linguistics. Beijing: Foreign Language Teaching and Research Press.

[13] Wen, Q. F. (2014). "The Controversy between General English and Special English in College English Teaching: Problems and Countermeasures." Foreign Languages and their Teaching (1):1-8.

[14] Wu, X. H. (2014). "A Study of Improving the English Proficiency of Non-English Major Graduate Students -- Taking Guangdong University of Foreign Studies as an Example.” Journal of Guangdong University of Foreign Studies (4): 94-97.

[15] Xia, J. M. (2002). The Theory and Practice of Modern Foreign Language Curriculum Design. Shanghai: Shanghai Foreign Languages Education Press.

[16] Xia, J. M. (2005). Senior English Reading and Writing: A Supplementary Lesson plan for Academic English. Shanghai: Shanghai Foreign Languages Education Press.

[17] Xu, J. Q. \& G. Y. Jiang. (2014). “The Concept of Curriculum Model Derived from Cognitive Needs.” Mind and Calculation (2): 64-69.

[18] Yang, X. L. \& X. Y. Yang. (2013). Academic English Writing. Shanghai: Shanghai Jiao Tong University press.

[19] Yang, B. J. (2009). The Writing Basis of Postgraduate English Academic Papers. Shanghai: Fudan University Press.

[20] Yin, Y. F. \& X. H. Wang. (2015). "A Probe into the Reform of English Testing Methods in Colleges and Universities: Inspiration from the Teaching and Assessment Methods of EAP in DIT.” Journal of Kaifeng Institute of Education (4): 58-60.

Yuan Kong received her M.A. degree in linguistics. She is currently a lecturer at the School of Foreign Languages, Jining Medical University, Jining, Shandong, China. She teaches various subjects including: English intensive reading, English extensive reading, listening, nursing reading and so on. Her research interests mainly include English language teaching, applied linguistics, cross-cultural communication, etc. 